\title{
Evaluasi Produktivitas Kacang Tunggak (Vigna unguiculata (L.) Walp) pada Dataran Menengah
}

\section{Productivity Evaluation of cowpea (Vigna unguiculata (L.) Walp) in Middle Plains}

\author{
Fachrul Rohimin Iska, Heni Purnamawati* dan Juang Gema Kartika
}

\author{
Departemen Agronomi dan Hortikultura, Fakultas Pertanian, Institut Pertanian Bogor \\ (Bogor Agricultural University), Jalan Meranti, Kampus IPB Darmaga, Bogor 16680, Indonesia \\ Telp. \& Faks. 0251-8629353 e-mail: agronipb@indo.net.id \\ *Penulis untuk korespondensi: heni_purnama@yahoo.com
}

Disetujui 14 Mei 2018/ Published online 21 Mei 2018

\begin{abstract}
This study was conducted to evaluate the productivity of cowpea (Vigna unguiculata (L.) Walp) in the middle plains. Research was conducted in the middle plains in Kampung Cisasah Rawasari, Ciomas, Bogor, West Java. Planting was done in April 2016 to July 2016. The research used Completely randomized design (RKLT) factor. There are five standard of treatment used is KT-1, KT-2, KT-6, KT-8 and KT-9. The treatment was repeated four times so that there are 20 experimental unit. Data analysis using $F$ test and if the results are real, then the test continued with DMRT (Duncan's Multiple Range Test) at $5 \%$ level. Do also test multiple variables correlation with productivity. The results showed that the treatment varieties significant effect on variables leaf area, number of pods per plant, weight of dry beans per plant, weight of dry pods per plant, seed yield, pod yield, as well as the treatment of varieties have real impact on the ability to grow crops and conductance plants. The characters are positively correlated and highly visible on the productivity of cowpea is a leaf angle to photosynthesis, leaf angle of the conductance, photosynthesis against conductance, number of pods on the dry weight of pods, pods of the dry weight of the seed, pod length to the number of seeds per pod, dry weight the seed pods dry weight, number of pods on the seed yield, number of pods on pod yield, dry weight of the seed pod yield.
\end{abstract}

Keywords: Evaluation, Plain Medium, Productivity

\section{ABSTRAK}

Penelitian ini dilakukan untuk mengevaluasi produktivitas kacang tunggak (Vigna unguiculata (L.) Walp) pada dataran menengah. Penelitian dilaksanakan pada dataran menengah di Kampung Cisasah Rawasari, Ciomas, Kabupaten Bogor, Jawa Barat. Penanaman dilakukan pada bulan April 2016 hingga Juli 2016. Penelitian menggunakan Rancangan Kelompok Lengkap Teracak (RKLT) satu faktor. Terdapat lima taraf perlakuan yang digunakan yaitu KT-1, KT-2, KT-6, KT-8 dan KT-9. Perlakuan diulang sebanyak empat kali sehingga terdapat 20 satuan percobaan. Analisis data mengunakan uji $\mathrm{F}$ dan apabila hasilnya nyata maka pengujian dilanjutkan dengan uji DMRT (Duncan's Multiple Range Test) pada taraf 5\%. Dilakukan juga uji korelasi beberapa peubah dengan produktivitas. Hasil penelitian menunjukkan bahwa perlakuan varietas berpengaruh sangat nyata terhadap peubah luas daun, jumlah polong per tanaman, bobot biji kering per tanaman, bobot polong kering per tanaman, hasil biji, hasil polong, serta perlakuan varietas berpengaruh nyata terhadap daya tumbuh tanaman dan konduktansi tanaman. Karakter yang berkorelasi positif dan sangat nyata terhadap produktivitas kacang tunggak adalah sudut daun terhadap fotosintesis, sudut daun terhadap konduktansi, fotosintesis terhadap konduktansi, jumlah polong terhadap bobot kering polong, jumlah polong terhadap bobot kering biji, panjang polong terhadap jumlah biji per polong, bobot kering polong terhadap bobot kering biji, jumlah polong terhadap hasil biji, jumlah polong terhadap hasil polong, bobot kering biji terhadap hasil polong.

Kata kunci: Dataran Menengah, Evaluasi, Produktivitas 


\section{PENDAHULUAN}

Kacang tunggak (Vigna unguiculata (L.) Walp) merupakan salah satu jenis kacangkacangan yang dapat dimanfaatkan sebagai substitusi kedelai dalam pembuatan tempe (Richana dan Damardjati, 1999). Kacang tunggak tanpa dicampur kedelai dapat menghasilkan tempe dengan kualitas yang baik (Purwani et al., 2006). Kacang tunggak termasuk tanaman multifungsi, seluruh bagian tanaman dapat dimanfaatkan sebagai sumber pangan dan pakan (Inaizumi et al., 1999). Tanaman ini secara fisiologis mampu beradaptasi luas dalam berbagai kondisi lingkungan.

Kacang tunggak di Indonesia ditanam diberbagai zona ekologi mulai dari dataran rendah hingga dataran tinggi, daerah beriklim kering hingga beriklim basah. Berbagai faktor mempengaruhi pertumbuhan dan produksi tanaman. Penelitian ini dilakukan untuk mendapatkan tambahan informasi faktor-faktor yang mempengaruhi pertumbuhan dan produksi kacang tunggak.

Kacang tunggak termasuk tanaman setahun yang mempunyai kisaran adaptasi cukup luas di daerah tropik dan subtropik beriklim kering hingga agak basah dengan curah hujan masingmasing lebih kecil $600 \mathrm{~mm}$ dan 100-1500 mm tahun-1. Kacang tunggak termasuk tanaman hari pendek yaitu berbunga lebih awal pada periode penyinaran yang lebih rendah (Karsono, 1998). Suhu optimum bagi pertumbuhan dan perkembangan kacang tunggak berkisar antara 25 ${ }^{\circ} \mathrm{C}$ sampai $30{ }^{\circ} \mathrm{C}$. Di bawah suhu $15{ }^{\circ} \mathrm{C}$ mengakibatkan tanaman tidak tumbuh normal bahkan dapat mati karena embun beku. Suhu di atas $35{ }^{\circ} \mathrm{C}$ dapat mengakibatkan kerontokan bunga dan polong.

\section{BAHAN DAN METODE}

Kegiatan penelitian dalam rangka evaluasi produktivitas kacang tunggak ini dilaksanakan di Kampung Cisasah Rawasari, Ciomas, Kabupaten Bogor, Jawa Barat. Penanaman dilakukan pada bulan April hingga Juli 2016. Faktor yang diuji adalah 5 varietas kacang tunggak yaitu V1 (KT1), V2 (KT-2), V3 (KT-6), V4 (KT-8), V5 (KT9). Penelitian ini menggunakan Rancangan Faktorial Kelompok Lengkap Teracak (RKLT) dengan satu faktor yaitu varietas. Percobaan dilakukan sebanyak empat ulangan dengan 20 petak satuan percobaan.

Bahan yang digunakan dalam penelitian ini adalah varietas kacang tunggak yang terdiri dari varietas KT-1, KT-2, KT-6, KT-8 dan KT-9.
Pupuk dasar yang digunakan adalah pupuk Urea, SP-36, KCl, dolomit, Carbofuran 3G, dan herbisida. Alat yang digunakan antara lain peralatan budidaya tanaman, mulsa plastik, ajir bambu, timbangan digital, oven, LICOR 3000, LICOR 6400, meteran, busur derajat, karung, kertas, label, penggaris, dan alat tulis.

Pelaksanaan penelitian dimulai dari persiapan tanam, penanaman dan pemupukan, pemeliharaan, pemanenan dan pengamatan percobaan. Persiapan tanam dimulai dengan mengolah tanah secara sempurna kemudian dibuat 20 petakan dengan ukuran $2 \mathrm{~m}$ x $1 \mathrm{~m}$. Selanjutnya dilakukan pembuatan bedengan dengan jarak antar bedengan $50 \mathrm{~cm}$. Seminggu sebelum tanam dilakukan penyemprotan herbisida glyphosat untuk mengendalikan pertumbuhan gulma sesuai kebutuhan di lahan. Sehari sebelum penanaman, lahan ditaburi dolomit dengan dosis $500 \mathrm{~kg} \mathrm{ha}^{-1}$ kemudian lahan ditutup dengan mulsa plastik.

Benih ditanam 3 benih per lubang dengan jarak tanam $50 \mathrm{~cm} \times 20 \mathrm{~cm}$ menggunakan sistem tugal. Insektisida berbahan aktif karbofuran ditaburkan bersamaan dengan benih tanaman dengan dosis $10 \mathrm{~kg} \mathrm{ha}^{-1}$ untuk mencegah serangan hama tanaman. Aplikasi pupuk menggunakan dosis urea $50 \mathrm{~kg} \mathrm{ha}^{-1}, \mathrm{SP}-36100 \mathrm{~kg} \mathrm{ha}^{-1}$, dan $\mathrm{KCl}$ $100 \mathrm{~kg} \mathrm{ha}^{-1}$, semua diberikan pada saat tanam dengan cara dilarik di samping barisan tanaman. Data iklim dikumpulkan sejak tanam hingga panen.

Kegiatan pemeliharaan tanaman meliputi penyiraman, penjarangan, penyiangan, serta pengendalian hama dan penyakit. Penyiraman dilakukan setiap hari sesuai kebutuhan tanaman. Penjarangan dilakukan pada 2 Minggu Setelah Tanam (MST) dengan menyisakan 2 tanaman yang memiliki pertumbuhan yang baik. Pertanaman diupayakan bersih dari gulma selama 5 minggu pertama dengan melakukan penyiangan secara manual pada 4 dan 7 MST. Serangan hama dan penyakit diupayakan serendah mungkin dengan penggunaan pestisida pada awal tanam serta dilakukan penyemprotan 2 minggu sekali mulai dari 5 MST hingga 10 MST.

Pengamatan akan dilakukan pada 5 tanaman contoh yang dipilih secara acak pada masing-masing varietas tiap satuan percobaan. Peubah yang diamati meliputi:

1. Daya tumbuh tanaman (\%)

Daya tumbuh tanaman dihitung berdasarkan perbandingan antara jumlah tanaman yang tumbuh dengan jumlah benih yang ditanam seluruhnya tiap unit percobaan. Pengamatan dilakukan pada 1 MST.

2. Sudut daun $\left({ }^{\circ}\right)$ 
Sudut daun merupakan sudut yang dibentuk oleh batang utama tanaman dengan tangkai daun, diukur menggunakan busur derajat.

3. Luas daun $\left(\mathrm{cm}^{2}\right)$

Luas daun dihitung pada saat $50 \%$ tanaman sudah berbunga. Luas daun diukur menggunakan alat leaf area meter.

4. Laju fotosintesis dan konduktansi stomata $\left(\mu \mathrm{mol} \mathrm{m} \mathrm{s}^{-2} \mathrm{~s}^{-1}\right)$

Laju fotosintesis dan konduktansi diukur menggunakan LICOR 6400 dilakukan pada pagi menjelang siang hari.

5. Jumlah polong per tanaman $(\mathrm{g})$ dan panjang polong $(\mathrm{cm})$

Jumlah dan panjang polong per tanaman dihitung dan diukur pada saat panen. Tanaman yang dipanen berjumlah \pm 36 tanaman.

6. Jumlah biji per polong

Jumlah biji per polong tanaman dihitung pada saat panen.

7. Bobot polong kering per tanaman $(\mathrm{g})$

Bobot polong diperoleh dengan cara ditimbang menggunakan timbangan digital setelah dikeringkan hingga mencapai suhu $80{ }^{\circ} \mathrm{C}$ selama 3 hari.

8. Bobot biji kering per tanaman (g)

Bobot biji kering ditimbang setelah biji dikeringkan.

9. Bobot 100 biji (g)

Bobot 100 biji diperoleh dengan menimbang 100 biji kacang tunggak yang diambil dari masing-masing tanaman contoh pada setiap petakan setelah panen.

10.Indeks panen

Rataan panen dihitung dengan menggunakan rumus (Sitompul dan Guritno, 1995):

$\mathrm{HI}=\frac{\mathrm{Y}}{\mathrm{W}}$

Keterangan:

HI : Harvest Index (Indeks panen)

$\mathrm{Y}$ : Bobot polong kering isi (g)

$\mathrm{W}$ : Bobot kering total tanaman $(\mathrm{g})$

11.Bobot biji kering per ubinan $\mathrm{m}^{2}(\mathrm{~g})$

Bobot biji kering per ubinan diperoleh setelah 36 tanaman panen dan biji hasil ubinan dikeringkan.

12.Laju Tumbuh Tanaman (LTT) $\left(\mathrm{g} \mathrm{m}^{-2}\right.$ hari $\left.^{-1}\right)$ Laju Tumbuh Tanaman (LTT) dihitung dengan menggunakan rumus seperti yang tercantum dalam Brown (1984) yaitu:
$\mathrm{LTT}=\frac{\mathrm{W} 2-\mathrm{W} 1}{\mathrm{t} 2-\mathrm{t} 1} \times \frac{1}{\mathrm{a}}$

Keterangan:

a : luas area tempat tumbuh tanaman $(\mathrm{m} 2)$

W2 : bobot kering tanaman awal $(\mathrm{g})$

$\mathrm{W} 1$ : bobot kering tanaman akhir (g)

t2 : waktu awal pengamatan (hari)

t1 : waktu akhir pengamatan (hari)

Data hasil pengamatan dianalisis dengan sidik ragam menggunakan Microsoft Excel, dan Software SAS 9.1 untuk mengetahui pengaruh perlakuan, apabila perlakuan berpengaruh nyata dilakukan uji lanjut DMRT dengan taraf $\alpha=5 \%$. Untuk analisis korelasi menggunakan software Minitab 16.

\section{HASIL DAN PEMBAHASAN}

Penelitian ini dilaksanakan di lahan sawah petani di Desa Purwasari, Kecamatan Dramaga, Kabupaten Bogor. Penelitian dilakukan ketika musim penghujan. Menurut Rumus Braak: suhu udara menurun sekitar 0,6 setiap kenaikan tinggi tempat 100 meter di permukaan bumi. Suhu ratarata maksimum tertinggi pada bulan April yaitu $30,9^{\circ} \mathrm{C}$, dan suhu rata-rata minimum pada bulan Juli yaitu $21{ }^{\circ} \mathrm{C}$.

Selama penelitian curah hujan rata-rata per bulan sebesar $388 \mathrm{~mm}$ dan kelembaban relatif rata-rata sebesar $83,903 \%$. Curah hujan tertinggi pada bulan April sebesar $558 \mathrm{~mm}$ bulan-1 dan terendah pada bulan Juli sebesar $292 \mathrm{~mm}$ bulan-1. Karsono (1998) melaporkan bahwa daerah kisaran adaptasi kacang tunggak meliputi daerah tropik beriklim kering sampai agak basah dengan curah hujan masing-masing lebih kecil $600 \mathrm{~mm}$ dan 1000-1500 mm tahun-1.

Hasil penelitian menunjukkan bahwa perlakuan varietas berpengaruh sangat nyata terhadap peubah luas daun, jumlah polong per tanaman, bobot biji kering per tanaman, bobot polong kering per tanaman, produktivitas biji, produktivitas polong, serta perlakuan varietas berpengaruh nyata terhadap daya tumbuh tanaman dan konduktansi tanaman. Nilai KK menunjukkan tingkat ketepatan pada perlakuan yang diperbandingkan dan merupakan indeks yang baik dari keadaan percobaan (Gomez dan Gomez, 2007). Nilai koefisien keragaman (KK) dari karakter yang diamati berkisar antara 4,06\% hingga $29,19 \%$. 
Tabel 1. Rekapitulasi hasil sidik ragam berbagai peubah pengamatan tanaman kacang tunggak

\begin{tabular}{|c|c|c|}
\hline Peubah & Perlakuan & Koefisien keragaman (\%) \\
\hline Daya tumbuh tanaman & $*$ & 4,06 \\
\hline Sudut daun & tn & 8,03 \\
\hline Luas Daun & ** & 13,23 \\
\hline Laju fotosintesis & tn & 5,48 \\
\hline Konduktansi stomata & $*$ & 29,19 \\
\hline \multicolumn{3}{|l|}{ Laju Tumbuh Tanaman (LTT) } \\
\hline 30-37 HST & tn & $22,38^{x}$ \\
\hline 37-42 HST & tn & 24,67 \\
\hline 42-80 HST & tn & $19,53^{\mathrm{x}}$ \\
\hline Jumlah polong tanaman ${ }^{-1}$ & ** & 8,71 \\
\hline Panjang polong tanaman ${ }^{-1}$ & tn & 5,26 \\
\hline Jumlah biji polong $^{-1}$ & tn & 6,65 \\
\hline Bobot biji Kering tanaman ${ }^{-1}$ & $* *$ & 9,98 \\
\hline Bobot polong Kering tanaman ${ }^{-1}$ & $* *$ & 8,22 \\
\hline Bobot 100 biji & th & 19,87 \\
\hline Indeks panen & tn & $7,22^{x}$ \\
\hline Produktivitas polong & ** & 8,22 \\
\hline Produktivitas biji & $* *$ & 7,59 \\
\hline
\end{tabular}

Keterangan: tn: tidak berbeda nyata berdasarkan uji DMRT pada taraf $\alpha=5 \%$, : berbeda nyata berdasarkan uji DMRT pada taraf $\alpha=5 \%, * *$ : berbeda sangat nyata berdasarkan uji DMRT pada taraf $\alpha=5 \%$, KK: koefisien keragaman, x: hasil transformasi $\sqrt{ } \mathrm{x}+0,5$.

\section{Evaluasi terhadap Karakter Vegetatif}

Daya Tumbuh Tanaman, sudut daun dan luas daun. Daya tumbuh tanaman dilakukan pada saat tanaman kacang tunggak berumur 7 HST. Hasil sidik ragam menunjukkan bahwa perlakuan varietas kacang tunggak memberikan pengaruh nyata terhadap peubah. Varietas KT-1 memiliki daya tumbuh tertinggi sebesar $93,72 \%$ namun tidak berbeda nyata dengan varietas KT-6, KT-8, dan KT-9. Daya tumbuh tanaman terendah diperoleh pada KT-2 yaitu sebesar $86,20 \%$ (Tabel 2)

Tabel 2.Rataan daya tumbuh, sudut daun dan luas daun tanaman kacang tunggak

\begin{tabular}{lccc}
\hline Perlakuan & Daya tumbuh $(\%)$ & Sudut daun $\left(^{\circ}\right)$ & Luas daun $\left(\mathrm{cm}^{2}\right)$ \\
\hline KT-1 & $93,72 \mathrm{a}$ & 84,00 & $118,21 \mathrm{a}$ \\
KT-2 & $86,20 \mathrm{~b}$ & 78,18 & $124,73 \mathrm{a}$ \\
KT-6 & $93,30 \mathrm{a}$ & 71,18 & $81,28 \mathrm{~b}$ \\
KT-8 & $89,55 \mathrm{ab}$ & 77,37 & $88,14 \mathrm{~b}$ \\
KT-9 & $88,72 \mathrm{ab}$ & 80,43 & $93,20 \mathrm{~b}$ \\
\hline
\end{tabular}

Keterangan: angka yang diikuti huruf yang sama pada kolom yang sama menunjukkan tidak berbeda nyata pada uji DMRT pada taraf $\mathrm{a}=5 \%$

Viabilitas benih yang baik dan ketersediaan air yang cukup diduga menjadi faktor utama yang mendukung perkecambahan benih kacang tunggak yang dibuktikan dengan daya tumbuh diatas $85 \%$. Kondisi benih yang tidak tumbuh diduga terserang cendawan karena tingkat kelembaban yang tinggi pada saat penanaman.

Pengamatan sudut daun dilakukan pada saat tanaman $50 \%$ berbunga. Perlakuan varietas tidak berpengaruh nyata terhadap sudut daun kacang tunggak. Rataan sudut daun tertinggi terdapat pada varietas KT-1 sebesar $84^{\circ}$ dan sudut daun terendah terdapat pada varietas KT-6 sebesar $71,18^{\circ}$. Sudut daun akan mempengaruhi penampilan tajuk tanaman. Sudut daun yang lebar menunjukkan cahaya matahari yang diterima daun bagian bawah untuk fotosintesis semakin berkurang.

Daun memiliki peranan penting sebagai tempat berlangsungnya fotosintesis dalam tanaman. Luas daun dapat dipengaruhi oleh jumlah daun dan luas daun. Hasil analisis ragam menunjukkan varietas berpengaruh sangat nyata terhadap peubah luas daun. Nilai luas daun ke 3 dari pucuk pada varietas KT-1 lebih baik dari empat varietas lainnya, yaitu sebesar $118,21 \mathrm{~cm}^{2}$ namun tidak berbeda nyata dengan KT-2. Nilai luas daun terendah terdapat pada varietas KT-6 sebesar $81,28 \mathrm{~cm}^{2}$ namun tidak berbeda nyata dengan varietas KT-8 dan KT-9. 


\section{Laju Fotosintesis dan Konduktansi Stomata}

Laju fotosintesis tanaman kacang tunggak diukur dengan menggunakan alat portable photosynthesis system yaitu LICOR 6400-XT. Pembukaan dan penutupan stomata ditentukan oleh tekanan turgor dari kedua sel penjaga, sementara itu tekanan turgor dipengaruhi oleh banyaknya air yang masuk ke sel penjaga (Lakitan, 2013).Daun merupakan salah satu organ tanaman yang menjadi tempat berlangsungnya proses fotosintesis yang menghasilkan karbohidrat. Karbohidrat hasil fotosintesis akan digunakan untuk pertumbuhan dan perkembangan organ-organ lainnya, Bleasdale (1973). Jumlah daun yang cukup merupakan syarat bagi tanaman untuk dapat melakukan fotosintesis secara optimal, sehingga dapat meningkatkan kualitas bunga dan polong berisi.
Hasil analisis ragam menunjukkan bahwa perlakuan varietas tidak berpengaruh nyata terhadap peubah laju fotosintesis (Tabel 3). Laju fotosintesis tertinggi terdapat pada varietas KT-1 sebesar $48,18 \%$ dan laju fotosintesis terendah pada varietas KT-6 sebesar 45,14\%. Gardner et al. (1991) menyatakan cahaya sangat diperlukan untuk pertumbuhan tanaman dan proses fotosintesis dimana hasil fotosintesis dialokasikan dalam bentuk bahan kering selama fase pertumbuhan, kemudian diakhir masa fase vegetatif fotosintat akan tertimbun pada organorgan tanaman seperti buah dan biji. Penurunan laju transpirasi ini ditandai dengan penyempitan dan/atau penutupan stomata, dan sebagian besar air yang keluar pada proses transpirasi adalah melalui stomata (Pallardy, 2008). Semakin banyak cahaya matahari yang didapat oleh tanaman, semakin baik pula pertumbuhan tanaman pada fase vegetatif sehingga pembentukan polong akan semakin baik.

Tabel 3. Rataan laju fotosinesis dan konduktansi tanaman kacang tunggak

\begin{tabular}{lcccc}
\hline Perlakuan & \multicolumn{2}{c}{$\begin{array}{c}\text { Fotosintesis } \\
\left(\mu \mathrm{mol} \mathrm{m}^{-2} \mathrm{~s}^{-1}\right)\end{array}$} & \multicolumn{2}{c}{$\begin{array}{c}\text { Konduktansi Stomata } \\
\left(\mu \mathrm{mol} \mathrm{m}^{-2} \mathrm{~s}^{-1}\right)\end{array}$} \\
\hline KT-1 & 48,18 & 24,72 & $0,30 \mathrm{a}$ & 0,38 \\
KT-2 & 45,41 & 25,43 & $0,22 \mathrm{ab}$ & 0,40 \\
KT-6 & 45,14 & 23,70 & $0,15 \mathrm{~b}$ & 0,36 \\
KT-8 & 47,85 & 25,50 & $0,27 \mathrm{ab}$ & 0,37 \\
KT-9 & 46,39 & 25,82 & $0,33 \mathrm{a}$ & 0,41 \\
\hline
\end{tabular}

Keterangan: angka yang diikuti huruf yang sama pada kolom yang sama menunjukkan tidak berbeda nyata pada uji DMRT 5\%, angka yang dicetak miring adalah hasil seminar Feri Vircue Z di ruang seminar AGH (19 Januari 2017)

\section{Laju Tumbuh Tanaman (LTT)}

Nilai LTT diperoleh melalui pengamatan destruktif dari empat tanaman selain tanaman contoh tiap satuan percobaan pada umur 30, 37, 42 HST (saat $50 \%$ berbunga), dan 80 HST (saat panen). Hasil analisis ragam menunjukkan bahwa perlakuan varietas tidak berpengaruh terhadap
LTT baik pada tahap pertumbuhan awal (30-37 HST), awal berbunga (37-42 HST), maupun pada fase reproduktif akhir (42-80 HST). Varietas yang memiliki nilai LTT tertinggi pada tahap pembungaan adalah KT-2 sebesar 14,15 $\mathrm{g} \mathrm{m}^{-2}$ hari $^{-1}$ (Gambar 1).

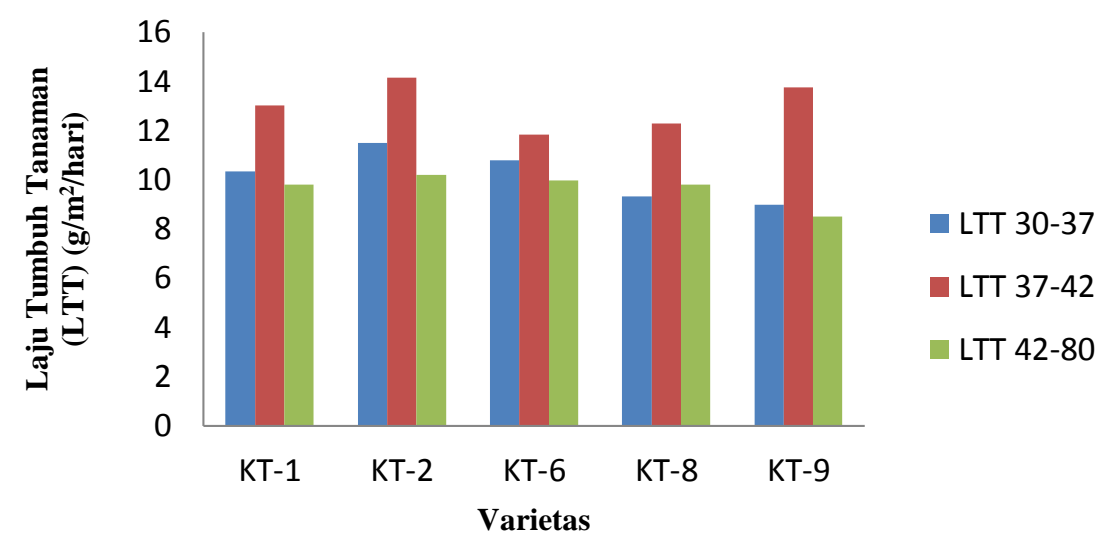

Gambar 1. Grafik rata-rata laju tumbuh tanaman 30, 37, 42, dan 80 HST 
Tabel 4. Rataan jumlah polong, jumlah biji dan panjang polong tanaman kacang tunggak

\begin{tabular}{lccc}
\hline Perlakuan & Jumlah polong per tanaman & Jumlah biji per polong & Panjang polong $(\mathrm{cm})$ \\
\hline KT-1 & $18,40 \mathrm{a}$ & 13,50 & 21,92 \\
KT-2 & $14,80 \mathrm{~b}$ & 14,30 & 23,33 \\
KT-6 & $18,10 \mathrm{a}$ & 14,30 & 23,15 \\
KT-8 & $16,35 \mathrm{ab}$ & 13,75 & 22,43 \\
KT-9 & $14,90 \mathrm{a}$ & 13,20 & 22,14 \\
\hline
\end{tabular}

Keterangan: angka yang diikuti huruf yang sama pada kolom yang sama menunjukkan tidak berbeda nyata pada uji DMRT 5\%

\section{Evaluasi terhadap Karakter Generatif}

Jumlah polong, jumlah biji dan panjang polong. Hasil analisis ragam menunjukkan bahwa perlakuan varietas berpengaruh sangat nyata terhadap peubah jumlah polong tanaman ${ }^{-1}$. Jumlah polong tertinggi terdapat pada varietas KT-1

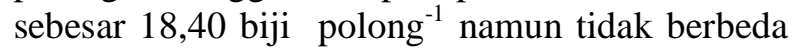
nyata dengan KT-6, KT-8 dan KT-9. Jumlah polong terendah terdapat pada varietas KT-2 sebesar 14,80 biji polong ${ }^{-1}$ (Tabel 4).

Hasil analisis ragam menunjukkan bahwa perlakuan varietas tidak berpengaruh nyata terhdap jumlah biji polong ${ }^{-1}$. Jumlah biji dalam polong tertinggi terdapat pada varietas KT-2 dan KT-6 sebesar 14,30 polong ${ }^{-1}$. Jumlah biji dalam polong terendah terdapat pada varietas KT-9 sebesar 13,20 biji polong ${ }^{-1}$.

Hasil analisis ragam pada panjang polong menunjukkan bahwa perlakuan varietas tidak berpengaruh nyata. Panjang polong tertinggi terdapat pada varietas KT-2 sebesar 23,33 dan nilai panjang polong terendah terdapat pada varietas KT-1 sebesar 21,92.

Tabel 5. Rataan bobot biji kering dan bobot polong kering tanaman kacang tunggak

\begin{tabular}{lcccccc}
\hline Perlakuan & \multicolumn{2}{c}{$\begin{array}{c}\text { Bobot polong kering } \\
\text { per tanaman }(\mathrm{g})\end{array}$} & \multicolumn{2}{c}{$\begin{array}{c}\text { Bobot biji kering } \\
\text { per tanaman }(\mathrm{g})\end{array}$} & \multicolumn{2}{c}{ Bobot $100 \mathrm{biji}(\mathrm{g})$} \\
\hline KT-1 & $14,49 \mathrm{ab}$ & 11,60 & $12,73 \mathrm{ab}$ & 4,35 & 12,97 & 12,17 \\
KT-2 & $12,33 \mathrm{c}$ & 10,20 & $10,43 \mathrm{c}$ & 5,53 & 12,76 & 13,81 \\
KT-6 & $14,86 \mathrm{a}$ & 8,56 & $13,22 \mathrm{a}$ & 3,75 & 12,69 & 12,44 \\
KT-8 & $13,08 \mathrm{bc}$ & 14,79 & $11,06 \mathrm{bc}$ & 7,08 & 12,47 & 12,21 \\
KT-9 & $11,91 \mathrm{c}$ & 10,01 & $9,74 \mathrm{c}$ & 4,58 & 12,77 & 12,97 \\
\hline
\end{tabular}

Keterangan: angka yang diikuti huruf yang sama pada kolom yang sama menunjukkan tidak berbeda nyata pada uji DMRT 5\%, angka yang dicetak miring adalah hasil seminar Feri Vircue Z di ruang seminar AGH (19 Januari 2017)

Hasil analisis ragam menunjukkan bahwa perlakuan varietas terhadap peubah bobot biji kering dan bobot polong kering berpengaruh sangat nyata (Tabel 5). Hasil bobot biji kering tertinggi terdapat pada varietas KT-6 sebesar 13,22 g namun tidak berbeda nyata dengan varietas KT-1 dan bobot biji kering terendah terdapat pada varietas KT-9 sebesar 9,74 g namun tidak berbeda nyata dengan KT-2 dan KT-8.

Hasil bobot polong kering tertinggi terdapat pada varietas KT-6 sebesar 14,86 g namun tidak berbeda nyata dengan varietas KT-1 dan bobot biji kering terendah terdapat pada varietas KT-9 sebesar 11,91 g namun tidak berbeda nyata dengan KT-2 dan KT-8.

\section{Indeks Panen}

Hasil analisis ragam menunjukkan bahwa perlakuan varietas tidak berpangaruh nyata terhadap peubah indeks panen. Indeks panen tertinggi terdapat pada varietas KT-6 sebesar 0,39 $\%$ dan indeks panen terendah terdapat pada varietas KT-2 sebesar $0,14 \%$ (Tabel 6).

Tabel 6. Rataan indeks panen tanaman kacang tunggak

\begin{tabular}{lccc}
\hline Perlakuan & Hasil polong (ton) & Hasil biji (ton) & Indeks panen \\
\hline KT-1 & $2,89 \mathrm{ab}$ & $1,15 \mathrm{ab}$ & 0,37 \\
KT-2 & $2,46 \mathrm{c}$ & $1,00 \mathrm{c}$ & 0,14 \\
KT-6 & $2,97 \mathrm{a}$ & $1,24 \mathrm{a}$ & 0,39 \\
KT-8 & $2,61 \mathrm{bc}$ & $1,10 \mathrm{bc}$ & 0,21 \\
KT-9 & $2,38 \mathrm{c}$ & $0,99 \mathrm{c}$ & 0,39 \\
\hline
\end{tabular}

Keterangan: angka yang diikuti huruf yang sama pada kolom yang sama menunjukkan tidak berbeda nyata pada uji DMRT 5\% 


\section{Analisis Korelasi}

Koefisien korelasi Pearson digunakan untuk mengukur kekuatan dan arah hubungan linier dari dua veriabel. Dua variabel dikatakan berkorelasi apabila perubahan salah satu variabel disertai dengan perubahan variabel lainnya, baik dalam arah yang sama ataupun arah yang sebaliknya. Nilai korelasi berkisar antara 1 sampai -1 , nilai semakin mendekati 1 atau -1 berarti hubungan antara dua variabel semakin kuat. Sebaliknya, jika nilai mendekati 0 berarti hubungan antara dua variabel semakin lemah. Nilai positif menunjukkan hubungan searah sementara nilai negatif menunjukkan hubungan terbalik (Mattjik dan Sumertajaya, 2013).

Karakter yang berkorelasi positif dan sangat nyata terhadap produktivitas kacang tunggak adalah sudut daun terhadap fotosintesis, sudut daun terhadap konduktansi, fotosintesis terhadap konduktansi, jumlah polong terhadap bobot kering polong, jumlah polong terhadap bobot kering biji, panjang polong terhadap jumlah biji per polong, bobot kering polong terhadap bobot kering biji, jumlah polong terhadap hasil biji, jumlah polong terhadap hasil polong, bobot kering biji terhadap hasil polong.

Lampiran 1. Korelasi antar karakter tanaman kacang tunggak

\begin{tabular}{|c|c|c|c|c|c|c|c|c|c|c|c|c|c|c|c|c|}
\hline & DT & SD & LD & $\mathrm{CO} 2$ & COUNT & JP & PJP & BKP & BKB & JBP & BB100 & IP & LTT1 & LTT2 & LTT3 & HB \\
\hline SD & 0,215 & & & & & & & & & & & & & & & \\
\hline LD & $-0,410$ & 0,218 & & & & & & & & & & & & & & \\
\hline $\mathrm{CO} 2$ & 0,289 & $0,605^{*}$ & 0,138 & & & & & & & & & & & & & \\
\hline COUNT & 0,054 & $0,684^{*}$ & 0,077 & $0,623 *$ & & & & & & & & & & & & \\
\hline JP & 0,240 & 0,000 & $-0,138$ & 0,125 & $-0,006$ & & & & & & & & & & & \\
\hline PJP & $-0,309$ & $-0,105$ & $-0,098$ & $-0,329$ & 0,050 & 0,012 & & & & & & & & & & \\
\hline BKP & 0,268 & $-0,159$ & $-0,207$ & $-0,047$ & $-0,155$ & $0,908^{* *}$ & 0,124 & & & & & & & & & \\
\hline BKB & 0,276 & $-0,171$ & $-0,220$ & 0,005 & $-0,138$ & $0,868 * *$ & 0,150 & $0,963 * *$ & & & & & & & & \\
\hline JBP & $-0,279$ & $-0,120$ & $-0,014$ & $-0,114$ & 0,065 & 0,275 & $0,784^{* *}$ & 0,192 & 0,219 & & & & & & & \\
\hline BB100 & $-0,025$ & $-0,182$ & $-0,085$ & 0,094 & 0,081 & 0,292 & 0,004 & 0,315 & 0,291 & 0,219 & & & & & & \\
\hline IP & 0,260 & 0,041 & $-0,282$ & 0,099 & $-0,038$ & 0,190 & 0,021 & 0,346 & 0,438 & $-0,078$ & $-0,144$ & & & & & \\
\hline LTT1 & $-0,125$ & $-0,232$ & 0,140 & $-0,233$ & $-0,157$ & $-0,056$ & 0,304 & $-0,030$ & 0,030 & 0,296 & 0,262 & 0,055 & & & & \\
\hline LTT2 & $-0,080$ & 0,062 & 0,002 & 0,008 & $-0,228$ & $-0,108$ & $-0,358$ & $-0,197$ & $-0,132$ & $-0,265$ & $-0,049$ & 0,089 & $-0,135$ & & & \\
\hline LTT3 & $-0,135$ & 0,032 & 0,198 & 0,117 & 0,221 & 0,023 & 0,409 & 0,010 & 0,010 & $0,554^{*}$ & 0,052 & $-0,036$ & $-0,047$ & $-0,168$ & & \\
\hline HB & $0,594 *$ & 0,070 & $-0,440$ & $-0,032$ & $-0,002$ & $0,569 *$ & 0,350 & 0,615 & $0,559 *$ & 0,338 & $-0,074$ & 0,255 & $-0,040$ & $-0,319$ & 0,186 & \\
\hline HP & 0,268 & $-0,159$ & $-0,207$ & $-0,047$ & $-0,155$ & $0,908 * *$ & 0,124 & $0,918^{* *}$ & $0,963^{* *}$ & 0,192 & 0,315 & 0,346 & $-0,030$ & $-0,197$ & 0,010 & $0,615^{*}$ \\
\hline
\end{tabular}

Keterangan: DT: Daya Tumbuh; SD: Sudut Daun; LD: Luas Daun; $\mathrm{CO}_{2}$ : Laju Fotosintesis; COUNT: Konduktansi Stomata; JP: Jumlah Polong per Tanaman; PP: Panjang Polong; BKP: Bobot Kering Polong per Tanaman; BKB: Bobot Kering biji per Tanaman; JBP: Jumlah Polong per Tanaman; BB100: Bobot Biji 100 butir; IP: Indeks Panen; LTT1: Laju Tumbuh Tanaman 37-30 HST; LTT2: Laju Tumbuh Tanaman 42-37 HST; LTT3: Laju Tumbuh Tanaman 80-42 HST; HB: Hasil Biji; HP : Hasil polong

\section{KESIMPULAN}

Terdapat pengaruh kelima varietas kacang tunggak yang diteliti terhadap faktor pertumbuhan luas daun dan konduktansi stomata, produktivitas juga dipengaruhi oleh varietas kacang tunggak. Varietas KT-1 memiliki pertumbuhan cukup baik dari varietas lain pada karakter daya tumbuh, luas daun, dan konduktansi stomata, serta memiliki kuantitas hasil tertinggi untuk karakter jumlah polong, bobot kering biji, bobot kering polong, produktivitas polong, produktivitas biji, indeks panen. Aspek morfologi panjang polong, dan jumlah polong mempengaruhi produksi biji kacang tunggak.

\section{DAFTAR PUSTAKA}

[Balitkabi] Badan Penelitian Tanaman Aneka Kacang dan Umbi. 2012. Deskripsi Varietas Ubi Jalar. [Internet] [diunduh 2016 Juli 30] tersedia pada http://balitkabi.litbang.pertanian.go.id/
[BPS] Badan Pusat Statistik. 2015. Produksi Ubi Jalar Menurut Provinsi. [Internet] [diunduh 2016 September 8] tersedia pada http://www.bps.go.id/

Bleasdale, J.K.A. 1973. Plant Physiology in Relation to Horticulture. London (UK). MacmillanPress LTD

Gardner, F.P., R.B. Pearce, R.L. Mitchel. 1991. Fisiologi Tanaman Budidaya. Penerbit UI Press, Jakarta.

Gomez, K. A., A.A. Gomez. 2007. Prosedur Statistik untuk Penelitian Pertanian. UI Press, Jakarta.

Inaizumi, H., B.B. Singh, P.C. Sanginga, V.M. Manyong, A.A. Adesina, S. Tarawali. 1999. Adoption and impact of dry-season dualpurpose cowpea in the semiarid zone of 
Nigeria. Ibadan: International Institute of Tropical Agriculture (IITA).

Karsono, S. 1998. Ekologi dan daerah pengembangan kacang tunggak di Indonesia. Hal:59-72. Dalam Kasno, A., A. Winarto (Eds.). Kacang Tunggak. Monograf Balitkabi No. 3.

Lakitan, B. 2013. Dasar-Dasar Fisiologi Tumbuhan. Rajawali Press, Jakarta. 35-62.

Mattjik, A.A., I.M. Sumertajaya. 2013. Perancangan Percobaan dengan Aplikasi SAS dan Minitab Jilid I. IPB Press, Bogor.
Pallardy, S.G. 2008. Transpiration and plant water balance. Dalam Physiology of Woody Plants. 3 edition. Elsevier-London, UK. 25366.

Richana, N., D.S. Damardjati. 1999. Karakteristik fisiko-kimia biji kacang tunggak (Vigna unguiculata (L.) Walp) dan pemanfaatannya untuk tempe. Penelitian Pertanian Tanaman Pangan. 18(1):72-77.

Sitompul, S.M., B. Guritno. 1995. Analisis Pertumbuhan Tanaman. UGM Press, Bandung 